\title{
Developing Visible Thinking and Motivation Through the Curricular Design of an Escape Room in Higher Education
}

\author{
Desarrollar el pensamiento visible y la motivación a través del diseño curricular de un \\ Escape Room en educación superior
}

\section{Desenvolver o pensamento visível e a motivação através do desenho curricular de um Escape room no Ensino Superior}

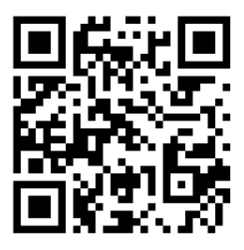

Naiara Bilbao-Quintana

Universidad del País Vasco

Leioa, España

naiara.bilbao@ehu.eus

(D) https://orcid.org/0000-0001-9876-4874

Arantzazu López-de-la-Serna

Universidad del País Vasco

Leioa, España

arantzazu.lopez@ehu.es

https://orcid.org/0000-0002-9297-8641

Ainara Romero-Andonegui

Universidad del País Vasco

Leioa, España

ainara.romero@ehu.eus

https://orcid.org/0000-0002-0132-9508

Eneko Tejada-Garitano

Universidad del País Vasco

Leioa, España

eneko.tejada@ehu.eus

https://orcid.org/0000-0002-6013-222X

Recibido • Received • Recebido: 14 / 11 / 2019

Corregido • Revised • Revisado: 19 / 07 / 2021

Aceptado • Accepted • Aprovado: 23 / 08 / 2021 
http://doi.org/10.15359/ree.25-3.27

http://www.una.ac.cr/educare

educare@una.ac.cr

\begin{abstract}
:
Introduction. The term escape room has undergone a notable evolution in recent years, extending its presence to areas not only recreational but also business or educational. The defining traits (overcoming obstacles, problem-solving, teamwork, time management...) have proven to be valid in business and education. This study presents the pedagogical design of an escape room based on visible thinking and analyses its effect on the motivation and cognitive processes of higher education students. Method. For this purpose, a quasi-experimental research with pretest/posttest was conducted, and it was evaluated whether the instructional design of the escape room was adequate to enhance the learning of the 238 students, whether it was motivating, and whether it contributed to the development of cognitive processes. We used two structured questionnaires with multiple-choice questions and one questionnaire with open-ended questions. We also applied a mixed method for quantitative and qualitative data collection and analysis. Results. The results show that the students consider the characteristics of the escape room and the organization of its elements to be of high quality; they also show that the curricular design of the escape room enhances students' learning. In particular, the students consider that they have developed group thinking, critical thinking, and the activation of prior knowledge through the escape room and have found it a motivating experience. Conclusions. The use of the escape room in educational environments has a high educational potential. This is not only because it encourages the development of higherorder cognitive processes but also because it contributes to teamwork, self-regulation, and student motivation. However, it must be designed as a significant part of the didactic program, taking special care in the development of competences and thinking.
\end{abstract}

Keywords: Escape Room; higher education; educational innovation; motivation, thinking.

\title{
Resumen
}

Introducción. El término escape room ha sufrido una notable evolución en los últimos años, extendiendo su presencia a ámbitos no solo lúdicos sino empresariales o educativos. Los rasgos que lo definen (superación de obstáculos, resolución de problemas, trabajo en equipo, gestión del tiempo...) han demostrado tener vigencia tanto en la empresa como en la educación. En este trabajo se presenta el diseño pedagógico de un escape room basado en el pensamiento visible, y se analiza su efecto sobre la motivación y los procesos cognitivos de estudiantes de educación superior. Metodología. Para ello, se llevó a cabo una investigación cuasi-experimental con pretest / post-test y se evaluó si el diseño instruccional del escape room era adecuado para potenciar el aprendizaje de los 238 estudiantes, era motivador y si contribuía al desarrollo de los procesos cognitivos. Se utilizaron dos cuestionarios estructurados con preguntas de opción múltiple y otro cuestionario con preguntas abiertas y se aplicó un método mixto de recogida y análisis de datos cuantitativos y cualitativos. Resultados. Los resultados muestran que el estudiantado considera que las características del escape room y la organización de sus elementos son de gran calidad y que su diseño curricular favorece su aprendizaje. En concreto, considera que a través del escape room han desarrollado el pensamiento grupal, el pensamiento crítico y la activación de conocimientos previos, y que les ha resultado una experiencia motivante. Conclusión. El uso del escape room en entornos pedagógicos tiene un alto potencial educativo. No solo porque favorece el desarrollo de los procesos cognitivos de orden superior, sino que, porque contribuye al trabajo en equipo, la autorregulación y la motivación estudiantil. Pero, para ello, debe diseñarse como parte significativa de la programación didáctica, poniendo especial cuidado en el desarrollo competencial y del pensamiento.

Palabras claves: Escape Room; educación superior; innovación educativa; motivación; pensamiento. 


\begin{abstract}
Resumo
Introdução. O termo escape room sofreu uma evolução notável nos últimos anos, estendendo sua presença não apenas para as esferas recreativas, mas também empresarial ou educacional. Seus traços definidores (superação de obstáculos, resolução de problemas, trabalho em equipe, gerenciamento do tempo ...) têm se mostrado válidos tanto nos negócios quanto na educação. Este documento apresenta a concepção pedagógica de um escape room com base no pensamento visível, e analisa o seu efeito sobre a motivação e os processos cognitivos dos estudantes do ensino superior. Metodologia. Para este efeito, foi realizada uma pesquisa quase experimental com pré-teste/pósteste e foi avaliado se a concepção instrucional do escape room era adequada para melhorar a aprendizagem dos 238 estudantes, se era motivadora e se contribuiu para o desenvolvimento de processos cognitivos. Foram utilizados dois questionários estruturados com perguntas de escolha múltipla e um questionário com perguntas abertas, e foi aplicado um método misto de coleta e análise de dados quantitativos e qualitativos. Resultados. Os resultados mostram que os estudantes consideram as características do escape room e a organização dos seus elementos como sendo de alta qualidade e que a sua concepção curricular favorece a sua aprendizagem. Especificamente, consideram que através do escape room desenvolveram o pensamento de grupo, o pensamento crítico e a ativação de conhecimentos anteriores, e que o consideraram uma experiência motivadora. Conclusão. A utilização do escape room em ambientes educativos tem um elevado potencial educativo. Não só porque favorece o desenvolvimento de processos cognitivos de ordem superior, mas também porque contribui para o trabalho de equipe, autorregulação e motivação dos estudantes. Mas para que isto aconteça, deve ser concebido como uma parte significativa do programa didático, prestando especial atenção ao desenvolvimento das competências e do pensamento.
\end{abstract}

Palavras-chave: Escape room; ensino superior; inovação educacional; motivação; pensamento.

\title{
Introduction
}

The term escape room has evolved from being known by a small group of people with a fairly defined profile (fans of role-playing games and video games) to become an expression with a presence in very different fields. From the media to leisure activities, through the workplace, it seems to have become a phenomenon mostly known and accepted at the social level (Byrd, 2016; Clarke et al., 2017; Kroski, 2019; Zhang et al., 2018).

In education, however, it seems that the introduction of the escape room has been carried out as just another element of gamification, without taking into account that it can become a gamified teaching-learning environment and that its pedagogical design must necessarily be planned. Studies that measure the involvement of escape rooms in learning focus on the effect of the game elements (Rapp et al., 2019), rather than on their pedagogical design and how they can generate playful, reflective, transformative and deep experiences (Contreras Espinosa \& Eguía Gómez, 2017). Indeed, evaluating how the pedagogical design of escape rooms (or other game-based learning environments) supports deep learning remains a challenge. However, it is the most important factor that distinguishes an educational game from a computer game (Malliarakis et al., 2014). 
http://doi.org/10.15359/ree.25-3.27

http://www.una.ac.cr/educare

educare@una.ac.cr

To address this issue, this research focuses on the pedagogical aspect of an escape room, studying its structure and how this can contribute to the learning experience if properly designed. Specifically, it highlights how it can encourage the use and development of the deep cognitive processes alluded to in the Making Thinking Visible theory (Ritchhart, 2002, 2015; Richhar \& Church, 2020; Ritchhar et al., 2011) and how it can raise the level of motivation of Higher Education students. With that goal, this research explains the conceptualization behind an escape room, its most relevant characteristics and its inclusion in the educational context. It then describes the basis of Making Thinking Visible and how this pedagogical proposal can contribute to the teaching-learning process.

\section{Theoretical framework}

\section{Definition}

There are several variants as to what makes up an escape room and there is no full unanimity as to the characteristics that it must have; Surprisingly, an escape room (or room from which to escape) does not even necessarily imply an escape plan as the ultimate goal or the very existence of a physical room (Clare, 2015).

The term seems to have its origin in the environment of video games (Kroski, 2019) and refers to games in which the action takes place in a variety of closed environments (prisons, dungeons, mansions, laboratories ...) but always with a common goal: being able to escape from the place where the protagonist is locked by solving puzzles, riddles, logic problems, etc.

To do this, he has several clues at his disposal, some more obvious than others, which he must collect and interpret to achieve this objective. Normally, the degree of difficulty in solving problems follows an increasing order, so that the motivation of the participants remains constant throughout the whole process (Kroski, 2019).

However, as mentioned above, the term has been extended to other situations in which physically escaping from a room is not the objective, while maintaining the resolution of problems and the gradual collection of clues as the main characteristic element. Finding an object, finding out a character's name or discovering a date can be the ultimate goal of the process. The process is the same, but using the term escape room in a more metaphorical way: the ignorance of what we are trying to discover is an imaginary space from which we want to escape through achievement and obtaining the answer.

\section{Features}

The definition of escape room varies depending on who uses the term and in what context it is applied, but nevertheless there are a number of characteristics that can be established as the most common features that make up an effective escape room (Borrego et al., 2017; Clare, 2015; Kalugin, 2019; Sierra Daza \& Fernández-Sánchez, 2019): 
http://doi.org/10.15359/ree.25-3.27

- Suggestive environment: normally thematic, with a setting that not only fulfills the function of containing the necessary elements for the resolution of the problem, but also supports it.

- Puzzles with varying degrees of difficulty: usually in increasing order, in order to maintain motivation throughout the process.

- Race against time: the fact of having a limited time implies, in addition to a challenge component that affects motivation, the need to carry out adequate time management.

- Teamwork: related to the previous point, having a limited amount of time to solve the challenges forces the participants to divide the tasks to be solved, so that each and every one of them contributes to the final success or failure.

- Clues: the resolution of problems is derived from the sum and interpretation of various clues.

- Argument and history: the existence of a motivating and coherent narrative gives a sense of unity to the process.

- Main game and secondary games: in this sense, it is usually customary for the main plot to be complemented by a series of secondary plots or secondary problems to solve, with their own entity, but immersed in the general narrative.

- Misplaced objects: this is usually one of the most traditional resources when presenting the clues or the information required to solve the most immediate problem.

- Use of patterns, symbols, codes, etc.: the use of alternative forms of communication puts into operation cognitive processes related to information coding.

\section{Escape rooms in business environments}

Perhaps the business environment is the area to which the practice of escape rooms has extended more rapidly and, according to recent studies, its advantages are several: they promote logical thinking, critical thinking and problem solving; create a strong feeling of teamwork, avoiding an excess of competitiveness or a rivalry of a toxic nature; they allow for closer ties with colleagues in an environment that is not strictly professional; they do not imply a strong investment of money, unlike other activities aimed at creating team feelings; and, finally, being raised as a scaled challenge to solve, makes them fun and motivating.

In addition to the aforementioned reasons, Meehan (2019) highlights its beneficial effect in achieving effective communication in work teams, assuming roles aimed at overcoming a goal and, finally, assertiveness and empowerment derived from joint problem solving. 
http://doi.org/10.15359/ree.25-3.27

http://www.una.ac.cr/educare

educare@una.ac.cr

\section{Escape rooms in educational environments}

Interestingly, many of the arguments that reflect the benefits that the practice of escape rooms can have in the workplace and professional, are applicable to the world of education. Aspects such as the use of logical thinking, the need to work in a team, the assumption of different roles within a group, etc. They are perfectly applicable to a learning environment.

More specifically, the following contributions from escape rooms to the teaching-learning process should be noted:

- Flexibility (Johnson, 2017): the very nature of the escape rooms makes any content, area, concept or material susceptible to being used. It is about designing the problems to be solved and the goal to reach using the elements of the area being worked on.

- Flexibility is extensible to the particular context in which it is applied (Nowco, 2016). It can be carried out as an inseparable part of the curriculum, as part of the teaching schedule but giving it an extracurricular character or even as a complementary activity outside the teaching schedule.

- They improve the retention of content and skills to be used, as reflected in a study carried out by researchers from the University of Granada (Gómez-Urquiza et al., 2018). Likewise, the participants highlighted the great motivational component that the escape room format contributed to learning.

- Another more recent study by the University of Ottawa (Kinio et al., 2019) has reached similar conclusions, highlighting the improvement in student satisfaction, participation and motivation.

- They give the student a leading role in the teaching-learning process (Johnson, 2017), also forcing him to assume responsibilities in decision-making and assess the different options he has when facing a problem.

- Improves the decoding of information of the participants, which affects a more efficient and effective problem solving (Hermanns et al., 2018; Ndulue et al., 2012).

- According to Kapp (2012), the use of mechanisms and environments typical of games (virtual or not), improves motivation, increases involvement and promotes problem solving and learning.

- Connect with the interests and concerns of the students; according to Nicholson (2013), providing the escape room with a narrative that connects with the sensitivity of those who participate in it, is an improvement in motivation and learning.

- Encourage curiosity in students, their desire to ask questions and their need to solve them, which, in turn, means they further expand their learning (Vörös \& Sárközi, 2017). 
http://doi.org/10.15359/ree.25-3.27

- Wiemker et al. (2015) also highlight the improvement derived from the use of escape rooms in the following cognitive processes: search, observation, correlation, memorization, pattern recognition and thought structuring.

- Finally, the study conducted by Clarke et al. (2017) reflects the benefit of using the escape room format in terms of student interest and motivation, in this case in the field of Higher Level Education.

Although the benefits of the use of escape rooms in the educational field are increasingly extensive, most research focuses on measuring or analyzing the implications on cognitive or psychological aspects of students (Connolly, 2013).

Therefore, there is still a lack of scientific literature that deepens the quality of teaching that can be imparted by incorporating an escape room into the teaching-learning processes and this study aims to contribute precisely to this. Thus, this study presents the pedagogical design of an escape room based on visible thinking, and analyses its effect on the motivation and cognitive processes of higher education students.

\section{Making Thinking Visible and its contribution to the teaching-learning process}

Visible Thinking (Gunawardena \& Wilson, 2021; Ritchhart, 2002, 2015; Ritchhart \& Church, 2020; Ritchhart et al., 2011) is a research line of Project Zero, an educational research group at the Graduate School of Education at Harvard University (Cambridge, Massachusetts, US). Its main goal from the beginning was to create a set of easily implemented tools (Tishman \& Andrade 1995) that would allow teachers to make the thinking processes that took place in the classroom visible.

Insisting on the concept of modeling, the researchers responsible for this proposal defend the usefulness of bringing the thinking of others to the surface, in order to be able to analyze it, take it as a reference and inspiration and improve it. From a cognitive point of view, as much emphasis is placed on the product as on the process that has been carried out to reach that product (Santamaría Mondragón, 2013; Swartz \& Parks 1994; Swartz \& Perkins, 1990).

They distinguish between two types of cognitive processes: primary and secondary. Examples of the first type would be synthesizing, inferring, interpreting, relating, adopting different points of view, etc. Examples of the second type would be observing, memorizing, reproducing, enunciating ... Both types of processes are necessary, but the latter have a more utilitarian role and are aimed at facilitating processes of a higher type, which are those that allow a deeper and longer-lasting understanding (de Bono, 1985; Salmon \& Barrera, 2021).

\section{Methodology}

For the purpose of this study, a cuasi-experimental research with pretest / post-test design is carried out (Ato et al., 2013). 
http://doi.org/10.15359/ree.25-3.27

http://www.una.ac.cr/educare

educare@una.ac.cr

Considering that the pedagogical design of an educational game is what promotes deep learning and what distinguishes it from a computer game (Malliarakis et al., 2014), in this study, in addition to evaluating the motivation and the development of the students' cognitive processes, we also wanted to evaluate the didactic design of the escape room. Due to the nature of the different variables and the instruments used to measure them, a mixed method has been used for quantitative and qualitative data collection and analysis.

Thus, this study aims to answer the following research questions:

- RQ1: Is the quality of the instructional design of the escape room adequate to enhance learning?

- RQ2: Does the use of escape rooms in a classroom context improve the degree of motivation shown by students?

- RQ3: Does the use of escape rooms in a classroom context imply the use of a greater variety of cognitive resources by students?

\section{Instruments}

In order to carry out this research, different evaluation instruments were used, as well as the didactic unit of the proposal and the escape room itself.

The Latin American version of the SEEQ survey, Students'Evaluation of Educational Quality, devised by Marsh (1982) and Andrade-Abarca et al. (2018). It is an instrument for assessment and improvement of teaching. Through this questionnaire, the effectiveness of teaching is analyzed and in turn it highlights or / and detects what areas of improvement should be taken into account. The factors, Satisfaction towards learning, Enthusiasm, Organization, Personal attitude and Evaluation, are assessed on a scale of 28 Likert-type items with five response options (1: strongly disagree, 2: disagree, 3: neither agree nor disagree, 4: agree and 5: strongly agree).

Academic achievement test: test to measure knowledge on the subject of educational assessment. The test consists of 16 questions with three answer options about knowledge:

- Assessment of learning within a competency framework

- Assessment as a process of improvement

- Learning assessment instruments

- Transfer of learning

Self-perception questionnaire: A form with open questions was designed to collect qualitative information of students regarding the cognitive processes used in escape and motivation. This form consisted of 10 items, all the questions being open. The aim was to avoid that participants were forced to choose among a limited number of possible answers; on the 
http://doi.org/10.15359/ree.25-3.27

contrary, questions were designed with a broader and more comprehensive nature, which allowed them to connect with different points of view and ways of focusing when answering. Of the 10 items, the first three refer to the type of cognitive processes used in performing the escape room. The next two show the degree of motivation achieved in its completion. The next two are related to the degree of autonomy with which they have managed to work. Finally, the last two items have to do with the type of teamwork they have performed throughout the test.

The 10 items of the questionnaire are detailed in the following Table 1.

Table 1: Escape room EHU - Evaluating what has been learned

P1. What different types of thinking have you had to put into practice to solve the challenge?

Cognitive processes P2. To what extent have you encountered a new context in which to apply what you have learned?

P3. What role has previously learned content played?

M4. How did the challenge posed refer to your most immediate reality?

M5. What possible different ways to overcome the challenge have you found?

A6. What degree of autonomy have you been forced to apply?

Autonomy A7. How have you planned the resolution of the challenge?

A8. What have been the main and secondary goals of the challenge?

TE9. What degree of collaboration within the group has been necessary to solve the challenge?

Teamwork

TE10. How have you defined the role of each group member?

Note: Own elaboration.

The Teaching Unit itself: the proposed challenge was that participants discovered why it is necessary to evaluate in the teaching-learning process. For this, a series of didactic objectives were raised, all of them formulated in terms of competence that is, including a content, a methodology and a transfer. For each of the objectives, three achievement indicators were defined, one for each integral part of the didactic objective. Thus, the skills could be worked in a global way.

The contents were classified as declarative, procedural and attitudinal.

The methodology included in the Didactic Unit is that of an educational escape room, with the characteristics previously mentioned in section 2 of this research, paying special attention to factors such as the environment, problem solving, time management, work team up...

Finally, the activities to be carried out by the participants were divided according to each of the phases of the Didactic Unit: Start Activities (presentation of the challenge), Process Activities (working with information and deepening), Final Activities (closing of problem solving) and Transfer Activities (application of what was learned in the context of each participant). 
http://doi.org/10.15359/ree.25-3.27

http://www.una.ac.cr/educare

educare@una.ac.cr

The digital Escape room: The activity was carried out with the application Genial.ly and comprised four rooms (Figure 1): 1) pre-game room: to present the story and explain the operation, 2) game room: game area itself with three challenges education to overcome cooperatively, 3) debriefing room: room for knowledge transfer, 4) monitoring room: for monitoring and support by teachers.

Figure 1: Main window of the Escape Room with access to the 4 rooms described

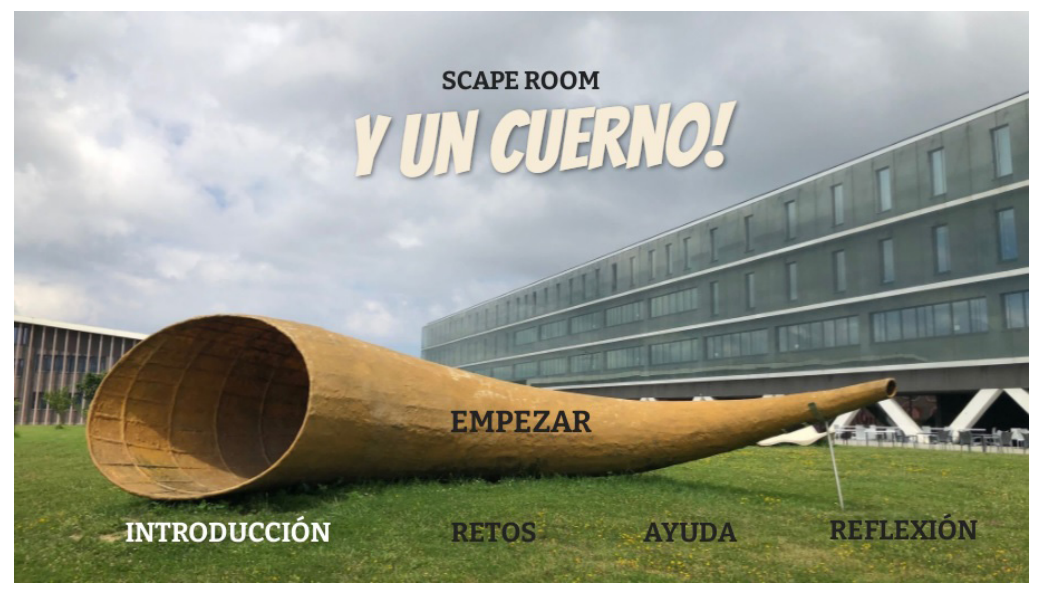

Note: Se reproduce con autorización de Naiara Bilbao bajo licencia CC BY-NC-ND

The main challenge in the escape room was to open the lock that closes the door to save the Acoustic Horn of the Faculty (emblematic sculpture of the Faculty). This main challenge was subdivided into three secondary challenges, in which the participants had to get a minimum score to get the combination that gave access to each of the safes of each challenge, three in total (see Figure 2).

In addition, environmental elements such as music and light were taken into account.

Figure 2: Game layout design

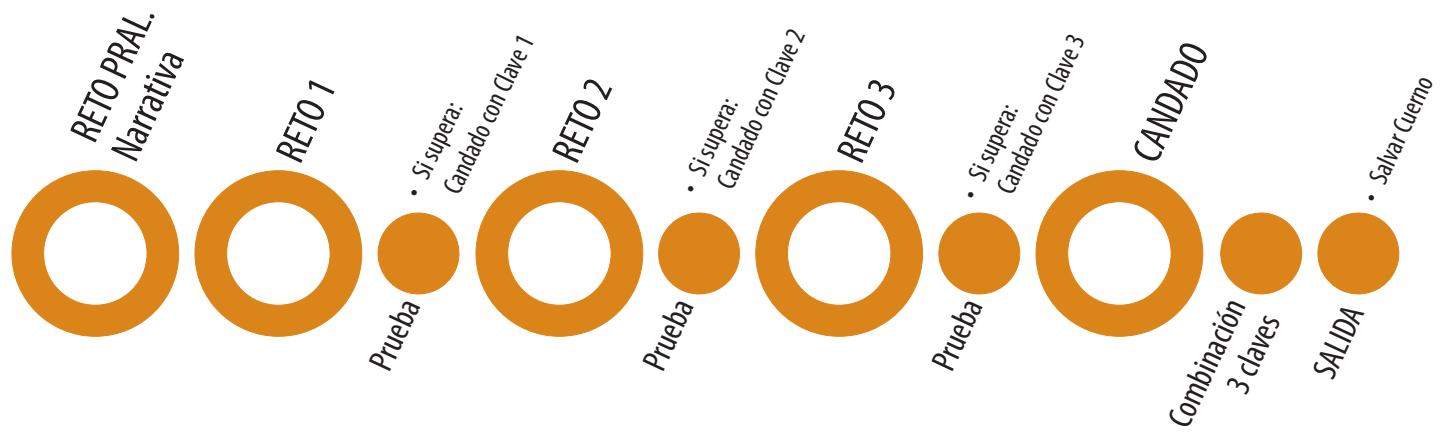

Note: Own elaboration. 
http://doi.org/10.15359/ree.25-3.27

\section{Participants}

Students from the degrees in Infant, Primary and Social Education who are studying the subject of General Didactic in the first year of their degree involve the convenience sample. Students had the opportunity to participate in the escape room experience on a voluntary way or to work on the content with the methodology used in the other topics of the subject (mostly theoretical expositions and classroom practices in groups).

In the end, 238 students decided to participate in the research. By degrees, Social Education (SE) comparatively contributed with the largest number of participants, 114, or what is the same, $47 \%$ of the total. Infant Education (IE) contributed with 44 students and Primary Education (PE) with 80 (17\% and 36\% respectively). Of the total, 180 participants were women (75\%) and 58 were men (25\%).

Finally, and in terms of age, $95 \%$ of the sample belonged to the age range between 18 and 25 , while only $5 \%$ belonged to the age range between 26 and 32 .

\section{Procedure}

This research was carried out entirely over 4 months, more specifically from March to June in 2019. The process began in March: the first step was the design of the escape room to be carried out by the students, taking into account the factors that would later be studied in the questionnaire and which have been previously described.

Subsequently, and withinthesamemonth, the necessary materials and resources werecollected to prepare the escape room in its final format. Throughout the month of April it was implemented in the degrees of Infant Education and Social Education. A month later, in May, it was implemented in the Primary Education degree. The duration of the escape room itself was a 120-minute session; previously, the dynamics and rules of the game had been explained to the participants.

Normal procedures of consent and confidentiality were followed during data collection. Thus, students were informed and gave their permission for the researchers to study their motivation, learning processes and their assessment of the escape room for both the intervention and evaluation phases. Data on academic performance were collected before and after the experience, using the Academic achievement test. The rest of the variables, motivation, cognitive processes and quality of the didactic design of the escape, were evaluated after the experience. The didactic design of the escape was evaluated through the answers given to the questionnaire "Student Evaluation of Educational Quality" (SEEQ) questionnaire (AndradeAbarca et al., 2018), which was used to collect quantitative information on 8 different aspects of teaching (Learning, Enthusiasm, Organization, Interaction with the group, Workload and difficulty, Exams/Tests, Relationship with the teacher and Escape Characteristics). On the other hand, the perception of motivation and the extent to which the use of an escape room facilitates 
http://doi.org/10.15359/ree.25-3.27

http://www.una.ac.cr/educare

educare@una.ac.cr

participants to put into practice higher order cognitive processes, were qualitatively assessed using the Self-perception questionnaire designed for this purpose.

After data collection, the analysis of the results and subsequent conclusions took place in the month of June.

\section{Results and Discussion}

The results are organized based on the research questions, and taking into account the intervention process, they are quantitative and qualitative.

\section{RQ1. Is the quality of the instructional design of the escape room adequate to enhance learning?}

A descriptive analysis of the results of the pre-post Academic achievement test was carried out, both at the global level (total sample) and by intervention group. An ANOVA test was performed which showed that at the time of pre-measurement there were no significant differences in learning achievements in any of the three groups $(F(2,235)=4.102 ; p=.093)$, so that we have similar groups for the intervention.

In comparing the pre and post measures of academic performance after the intervention, students by grade, as well as students as a total, obtained significant differences in improved academic performance, as shown by the means and mean differences in Table 2.

Table 2: Summary of descriptive data and comparison of means on pre-post Academic achievement test results

\begin{tabular}{|c|c|c|c|c|c|c|}
\hline & & $\mathrm{N}$ & Mean & Standard deviation & $t$ & $p$ \\
\hline \multirow{2}{*}{ IE } & RENDIM_PRE & 44 & 7,6932 & 1,01853 & 21,840 &, 000 \\
\hline & RENDIM_POST & 44 & 13,4773 & 1,62092 & & \\
\hline \multirow{2}{*}{ PE } & RENDIM_PRE & 80 & 7,6000 & 1,11492 & 27,556 &, 000 \\
\hline & RENDIM_POST & 80 & 13,4125 & 1,58868 & & \\
\hline \multirow[t]{2}{*}{ SE } & RENDIM_PRE & 114 & 7,6272 & 1,12850 & 31,035 & ,000 \\
\hline & RENDIM_POST & 114 & 13,4474 & 1,65680 & & \\
\hline \multirow{2}{*}{ Total } & RENDIM_PRE & 238 & 7,6303 & 1,10037 & 46,871 &, 000 \\
\hline & RENDIM_POST & 238 & 13,4412 & 1,62090 & & \\
\hline
\end{tabular}

Note: Maximum score of the Academic achievement test $=16$ points. Authors' own elaboration. 
http://doi.org/10.15359/ree.25-3.27

The quality of the instructional design of the escape room has been measured through the SEEQ questionnaire. The results show that the students are quite satisfied in the 8 aspects evaluated on teaching taught through Escape (see Table 3). All values are close to score 4 (in a maximum of 5), highlighting the characteristics of the Escape and its organization as the best rated dimensions.

Table 3: Summary of the means and standard deviations in the dimensions of the SEEQ

\begin{tabular}{lccc}
\hline \multicolumn{1}{c}{ Dimensions of the SEEQ } & $\mathrm{N}$ & Mean & $\begin{array}{c}\text { Dev. } \\
\text { Deviation }\end{array}$ \\
\hline Learning & 238 & 3,74 &, 92 \\
Enthusiasm & 238 & 3,74 & 1,11 \\
Organization & 238 & 3,88 &, 85 \\
Interaction with the group & 238 & 3,72 & 1,05 \\
Relationship with the teacher & 238 & 3,81 & 1,08 \\
Evaluation & 238 & 3,66 &, 85 \\
Difficulty of work & 238 & 3,70 &, 92 \\
Escape Features & 238 & 3,93 &, 89 \\
\hline
\end{tabular}

Note: Own elaboration.

However, the comparison of the results according to degree programme shows significant differences between the students' opinions towards the quality of the instructional design of the escape room $(F(2,227)=63.987 ; p=.000)$. The average graph (see Figure 3 ) shows that Social Education students are those who value the design of the escape room the least, with a total average of $3.05(\mathrm{sd}=0.75)$, compared to the average obtained by IE students $(\mathrm{M}=4.01 ; \mathrm{sd}=0.31)$.

Finally, analysing the relationship between students' post-intervention performance and their perception of the quality of the didactic design of the escape room, a simple lineal regression was applied. The results show that the lineal correlation coefficient is $R^{2}=0.645$, which suggests that $64.5 \%$ of the variability of the students' achievement results are related to how they perceive the design of the escape room. Furthermore, the ANOVA test indicates that the relationship between $t$ both variables is significant, $F(2,10)=17.85 ; p=.003$. 
http://doi.org/10.15359/ree.25-3.27

http://www.una.ac.cr/educare

educare@una.ac.cr

Figure 3: SEEQ average results graph according to education degree

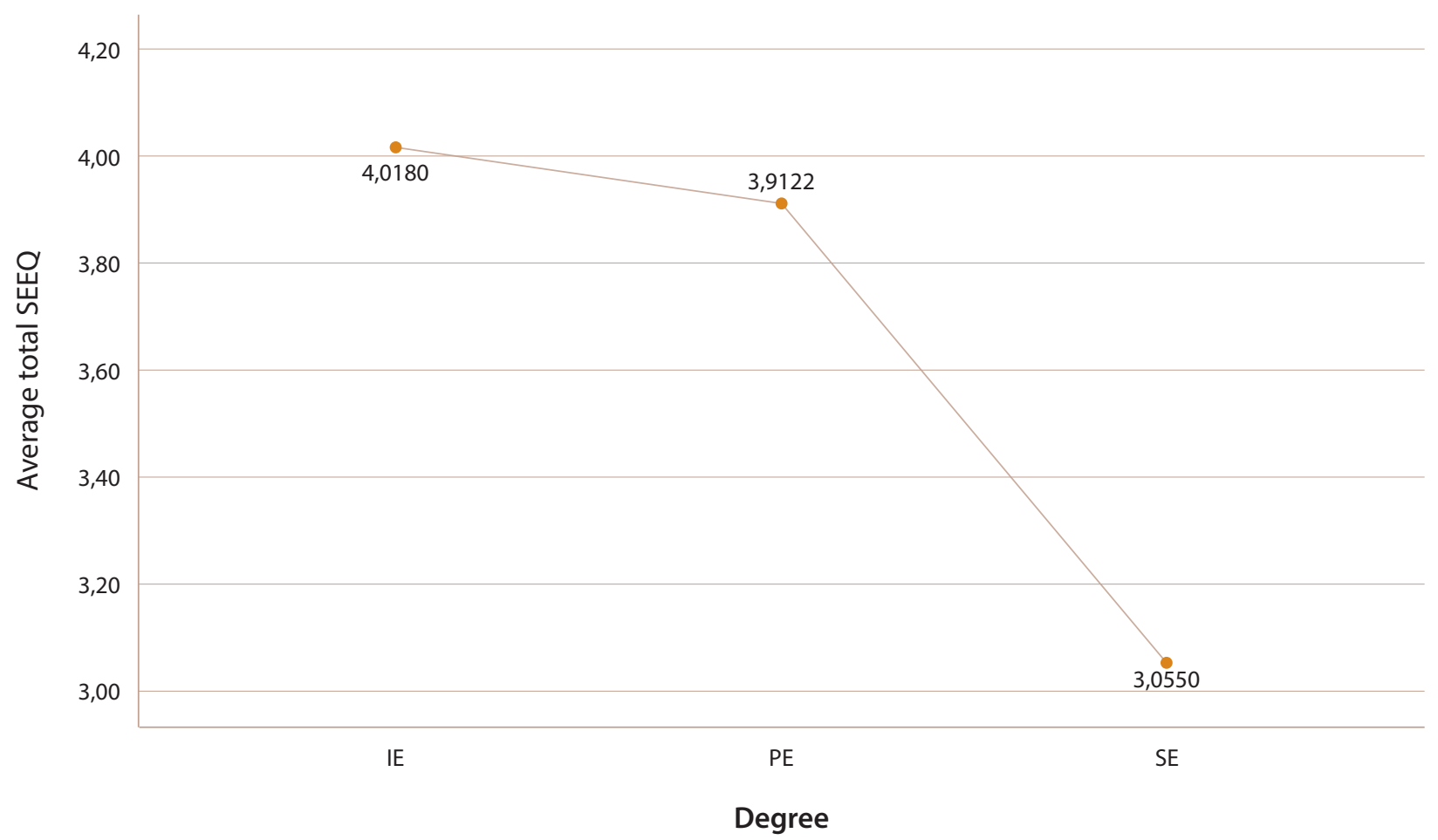

Note: Own elaboration.

\section{RQ2: Does the use of escape rooms in a classroom context improve the degree of motivation shown by students?}

Students' motivation was assessed through the qualitative answers given in the Selfperception questionnaire. Specifically, to answer this research question, we took into account the students' responses to the Motivation, Autonomy and Teamwork dimensions. A total of 47 responses were received and analysed.

The participants highlighted the motivational component that solving problems of increasing complexity had involved. One student said that this approach had helped him "feel like moving forward with problems"; Another participant mentioned that the use of the escape room format had meant "a way of working much more fun than the traditional one". Several participants insisted that this format implied "a more enjoyable way of working" and that learning not only was not impaired, but was reinforced because of a much more "motivating and suggestive" approach. Finally, a large majority of participants highlighted as elements that contributed to increase motivation the need to properly manage time (being forced to"prioritize 
http://doi.org/10.15359/ree.25-3.27

some steps over others"), the setting (making them believe they lived "part of an adventure") and teamwork (allowing them to appreciate "the strengths of others" when solving problems).

These results are in line with the data obtained from the SEEQ questionnaire. In both instruments, the students' perception of the motivation to escape and the team work needed to solve the challenges are perceived as positive.

\section{RQ3: Does the use of escape rooms in a classroom context imply the use of a greater variety of cognitive resources by students?}

The type cognitive processes used by the students in the execution of the escape room was evaluated by the questions in the "cognitive processes" section of the Self-perception questionnaire. In relation to the first and third questions (Q1. What different types of thinking have you had to put into practice to solve the challenge?, Q3. What role has previously learned content played?), students show a substantial change in the type of cognitive processes involved in the performance and resolution of activities. It is noteworthy that a large majority of students highlight group-thinking as one of the most activated cognitive processes, followed by critical thinking and the activation of prior knowledge. Moreover, there are students who indicate that it would not be possible to carry out the escape without activating prior knowledge ("It would be impossible to do this Escape room if you didn't know the concepts you'd learned"). It should be noted that around $20 \%$ of those questioned also showed that they needed group thinking to make progress in the escape ("Group strategies", "Group trust and active hearing strength"; "Group thinking, division work"; "Group organizing").

Finally, with regard to the second research question (Q2. To what extent have you encountered a new context in which to apply what you have learned?), the students point out that what they have learned about evaluation can be applied to the rest of tasks in which they have to carry out a didactic design ("I'Il use what I learned in other career lessons"). But they also underline that as teachers they would like to use this type of active and fun educational resources with their future pupils ("As an educator, I'd like to be able to make resources like this one day, it's a good way to learn and have fun").

\section{Discussion and Conclusion}

The main objective of this study was to evaluate the quality of the instructional design of an escape room based on visible thinking and to analyse how it contributes to the development of the cognitive and motivational processes of Higher Education students. To this end, the first study analysed the students' perception of the quality of the instructional design of the escape room and its contribution to the development of student learning. The comparison of the results in academic achievement before and after implementing the escape room and the results on the perception of the curriculum design of the escape room, reflect that the quality of 
http://doi.org/10.15359/ree.25-3.27

http://www.una.ac.cr/educare

educare@una.ac.cr

the instructional design of the escape room is adequate to improve learning. The students who participated in the experience highlight the features of the Escape Room and its organization as the best elements of the Escape Room curriculum design. The results also relate their positive perception of the escape design to improved academic performance. Although no studies have been found that relate the curriculum design of gamified environments to learning development, other studies have shown that game features contribute to learning (Kapp, 2012; Vörös \& Sárközi, 2017).

A second study has aimed to analyse the motivation of the designed escape room. The results obtained reveal significant improvements in several areas such as the degree of motivation achieved with this didactic unit design. This is in line with other studies that have shown that the use of gamification and escape room elements improve student motivation (Clarke et al., 2017; Gómez-Urquiza et al., 2018; Kapp, 2012; Nicholson, 2013), mainly because, when classroom work is organised on the basis of rewards, students become more involved (Kinio et al., 2019). However, it would be advisable to investigate whether the right balance between extrinsic and intrinsic motivation is achieved. An inadequate approach to the activity may result in the motivation of the learner being based solely on overcoming a series of tests or challenges of increasing difficulty. Motivation for their own learning and for the nature of what they are studying is neglected. Therefore, in future studies, it would be advisable to study the type of motivation that is generated in the participants and the extent to which it is given.

Finally, as opposed to the type of processes that traditional education normally requires (memorisation, reproduction, etc.), a third study was carried out to assess the students'opinions about whether this pedagogical proposal encourages students to put into practice other types of cognitive processes of a more complex nature: extrapolating, inferring, synthesising, etc. The students underline that the escape room facilitates group thinking above all, followed by critical thinking and the activation of prior knowledge. Thus, the designed escape roon leads the student to implement higher cognitive processes, which go further than the memoristic reproduction of content; which is in line with a challenge- and project-oriented type of classroom work (Johnson, 2017). It also involves a remarkable development of the participants' social skills, because cooperative work is a prerequisite for problem solving; if the activity is well designed, it should not be able to be carried out without cooperation between group members (Wiemker et al., 2015). Therefore, challenge-based classroom work implies a more creative, less linear and, overall, more complex type of thinking: having to put what they have learned into practice in new contexts requires participants to assimilate and internalise what they are working with. Other studies have also shown an improvement derived from the use of escape rooms in the following cognitive processes: search, observation, correlation, memorisation, pattern recognition and structuring of thought (Wiemker et al., 2015). 
In short, it can be concluded that when an escape room is adequately designed and focuses on the development of thinking, it contributes positively to the teaching-learning process. This is not only because it encourages the development of higher order cognitive processes, but also because it promotes teamwork, self-regulation and student motivation. Like any other tool with educational objectives, it must be carefully designed and structured so that it actually brings added value to the classroom work and for it to achieve deeper and lasting learning; it is not about converting the resource of an escape room into an end in itself, but rather in a means subject to learning objectives, to which one must devote the time required to be properly integrated into the planning of classroom work. It is of little use to plan the classroom work around an escape room if there has been no previous planning and reflection work about how this formula fits into the curricular context (Clare, 2015; Melendez, 2015; Pedersen, 2016).

\section{Declaración de Material complementario}

Este artículo tiene disponible, como material complementario:

-La versión preprint del artículo en https://doi.org/10.5281/zenodo.4412012

\section{References}

Andrade-Abarca, P. S., Ramón-Jaramillo, L. N., \& Loaiza-Aguirre, M. I. (2018). Aplicación del SEEQ como instrumento para evaluar la actividad docente universitaria. Revista de Investigación Educativa, 36(1), 259-275. https://doi.org/10.6018/rie.36.1.260741

Ato, M., López, J. J., \&Benavente, A. (2013). Un sistema de clasificación de los diseños de investigación en psicología. Anales de Psicología, 29(3), 1038-1059. https://revistas.um.es/ analesps/article/view/analesps.29.3.178511/152221

Borrego, C., Fernández, C., Blanes, I., \& Robles, S. (2017). Room escape at class: Escape games activities to facilitate the motivation and learning in computer science. Journal of Technology and Science Education, 7(2), 162-171. https://doi.org/10.3926/jotse.247

Byrd, C. M. (2016). Facilitating team-building sessions: A guide for escape room and exit Game owners. CreateSpace Independen Pulishing Platform. https://amz.run/3qLp

Clare, A. (2015). Escape the Game: How to Make Puzzle and Escape Rooms. Wero Creative Press.

Clarke, S., Peel, D. J., Arnab, S., Morini, L., Keegan, H., \& Wood, O. (2017). EscapED: A Framework for Creating Educational Escape Rooms and Interactive Games to For Higher/Further Education. International Journal of Serious Games, 4(3), 73-86. https://dx.doi.org/10.17083/ ijsg.v4i3.180 
http://doi.org/10.15359/ree.25-3.27

http://www.una.ac.cr/educare

educare@una.ac.cr

Connolly, T. M. (Ed.). (2013). Psychology, Pedagogy, and Assessment in Serious Games. IGI Global.

Contreras Espinosa, R.S. \& Eguía Gómez, J. L. (2017). Gamification en educación: Diseñando un curso para diseñadores de juegos. Revista KEPES, 14(16), 91-120. 10.17151/ kepes.2017.14.16.5

De Bono, E. (1985). Six thinking hats: An essential approach to business management from the creator of lateral thinking. Little Brown and Company.

Gómez-Urquiza, J. L., Gómez-Salgado, J., Albendín-García, L., Correa-Rodríguez, M., GonzálezJiménez, E., \& Cañadas-de la Fuente, G. A. (2018). The impact on nursing students' opinions and motivation of using a "Nursing Escape Room' as a teaching game: A descriptive study. Nurse education today, 72, 73-76. https://doi.org/10.1016/j.nedt.2018.10.018

Gunawardena, M \&Wilson, K. (2021). Scaffolding students' critical thinking: A process, not an end game. Thinking Skills and Creativity, 41, 1-10. https://doi.org/10.1016/j.tsc.2021.100848

Hermanns, M., Deal, B., Campbell, A. M., Hillhouse, S., Opella, J. B., Faigle, C., \& Campbell, R. H. (2018). Using an "Escape Room" toolbox approach to enhance pharmacology education. Journal of Nursing Education and Practice, 8(4), 89-95. https://doi.org/10.5430/jnep. v8n4p89

Johnson, H. E. (2017). Breaking Into Breakout Boxes: Escape Rooms in Education. https://amz. run/3qLy

Kalugin, V. (2019). An ideal escape room: Tips for creating games for novice owners escape rooms. https://amz.run/3ruy

Kapp, K. M. (2012). The gamification of learning and instruction: Game-based methods and strategies for training and education. John Wiley \& Sons.

Kinio, A. E., Dufresne, L., Brandys, T., \& Jetty, P. (2019). Break out of the Classroom: The use of Escape Rooms as an Alternative Teaching Strategy in Surgical Education. Journal of Surgical Education, 76(1), 134-139. https://doi.org/10.1016/j.jsurg.2018.06.030

Kroski, E. (2019). Escape Rooms and Other Immersive Experiences in the Library. American Library Association.

Malliarakis, C., Satratzemi , M., \&Xinogalos, S. (2014). Designing educational games for computer programming: A holistic framework. EJEL. Electronic Journal of e-Learning, 12(3), 281-181. https://academic-publishing.org/index.php/ejel/article/view/1699/1662

Marsh, H. W. (1982). SEEQ: A reliable, valid, and useful instrument for collecting students' evaluations of university teaching. British Journal of Educational Psychology, 52(1), 77-95. https://doi.org/10.1111/j.2044-8279.1982.tb02505.x 
Meehan, J. (2019). EDrenaline Rush: Game-changing Student Engagement Inspired by Theme Parks, Mud Runs, and Escape Rooms. Dave Burgess Consulting. https://amz.run/3qPQ

Melendez, S. (2015). How to Design an Escape Room. Fast Company [website]. https://bityl.co/44Gh

Ndulue, U., Peréa, F. C., Kayou, B., \& Martinez, L. S. (2012). Team-building activities as strategies for improving community-university partnerships: Lessons learned from Nuestro Futuro Saludable. Progres Community Health Partnerships: Research, Education, and Acticion, 6(2): 213-218. https://doi.org/10.1353/cpr.2012.0030

Nicholson, S. (2013). Exploring Gamification Techniques for Classroom Management, Paper Presented at Games Learning Society 9.0 [Preprint]. Madison, Wisconsin. http:// scottnicholson.com/pubs/gamificationtechniquesclassroom.pdf

Nowco, E. (2016). Escape Room Rules. How to Create an Amazing Game. https://amz.run/3qM0

Pedersen, F. (2016). 101 best escape room puzzle ideas. Now escape [blog]. https://bityl.co/44GZ

Rapp, A., Hopfgartner, F., Hamari, J., Linehan, C., \& Cena, F. (2019). Strengthening gamification studies: Current trends and future opportunities of gamification research. International Journal of Human-Computer Studies, 127, 1-6. https://www.researchgate.net/ publication/328944804 Strengthening gamification studies Current trends and future opportunities of gamification research

Ritchhart, R. (2002). Intellectual character: What it is, why it matters, and how to get it. Jossey-Bass. https://amz.run/4kTT

Ritchhart, R. (2015). Creating cultures of thinking: The 8 forces we must master to truly transform our schools. Jossey-Bass. https://amz.run/4kTS

Ritchhart, R. \& Church, M. (2020). The power of making thinking visible: Practices to engage and empower all learners. Jossey-Bass.

Ritchhart, R., Church, M., \& Morrison, K. (2011). Making thinking visible. How to promote engagement, understanding, and independence for all learnes. Jossey-Bass.

Salmon, A. K. \& Barrera, M. X. (2021). What are you thinking? Scaffolding thinking to promote learning. Young Children, 76(2), 59-63. https://www.naeyc.org/resources/pubs/yc/ summer2021/scaffolding-thinking-promote-learning

Santamaría Mondragón, B. (2013). Pensamiento visible y currículo oculto. Poiésis, (25), 1-5. https://doi.org/10.21501/16920945.633 
http://doi.org/10.15359/ree.25-3.27

http://www.una.ac.cr/educare

educare@una.ac.cr

Sierra Daza, M. C. \& Fernández-Sánchez, M. R. (2019). Gamificando el aula universitaria. Análisis de una experiencia de Escape Room en educación superior. Revista de Estudios y Experiencias en Educación, 18(36), 105-115. https://doi.org/10.21703/rexe.20191836sierra15

Swartz, R. J. \& Parks, S. (1994). Infusing the teaching of critical and creative thinking into content instruction: A lesson design handbook for the elementary grades. Critical Thinking Press and Software.

Swartz, R. \& Perkins, D. N. (1990). Teaching thinking: Issues and approaches. Revised edition. The practitioners' guide to yeaching thinking series. Midwest Publications Critical Thinking Press and Software.

Tishman, S. \& Andrade, A. (1995). Thinking dispositions: A review of current theories, practices, and issues. Harvard University.

Vörös, A. I. V. \& Sárközi, Z. (2017). Physics escape room as an educational tool. AIP Conference Proceedings, 1916(1), 050002-1-050002-6. AIP Publishing. https://doi. org/10.1063/1.5017455

Wiemker, M., Elumir, E., \& Clare, A. (2015). Escape Room Games. "Can you transform an unpleasant situation into a pleasant one?". https://bityl.co/44F0

Zhang, X. C., Lee, H., Rodriguez, C., Rudner, J., Chan, T. M., \& Papanagnou, D. (2018). Trapped as a Group, Escape as a Team: Applying Gamification to Incorporate Team-building Skills Through an 'Escape Room' Experience. Cureus, 10(3), 1-9. https://doi.org/10.7759/ cureus.2256 